\title{
CRITICAL FACTORS ASSOCIATED WITH THE ACCESS TO BANK CREDIT: AN EXPLORATORY STUDY
}

\author{
Ali Raza Elahi ${ }^{*}$, Alia Ahmed ${ }^{2}$, Safyan Majid $^{3}$, Muhammad Farhan Asif ${ }^{4}$ \\ ${ }^{1 *} \mathrm{Ph} . D .$, Scholar, National College of Business Administration \& Economics, Lahore, Pakistan; ${ }^{2}$ Dean, School of \\ Business Administration, National College of Business Administration \& Economics, Lahore, Pakistan; ${ }^{3} \mathrm{Ph} . \mathrm{D}$., Scholar, \\ University of Lahore, Lahore, Pakistan; ${ }^{4} \mathrm{Ph}$.D. Scholar, National College of Business Administration \& Economics, \\ Lahore, Pakistan.
}

Email: ${ }^{1 *}$ alirazaellahi@gmail.com, ${ }^{2}$ dralia@ @ ncbae.edu.pk, ${ }^{3}$ safyanmajid@gcu.edu.pk, ${ }^{4}$ farhanmalik510@ gmail.com Article History: Received on $17^{\text {st }}$ April 2021, Revised on $30^{\text {th }}$ April 2021, Published on $4^{\text {th }}$ May 2021

\begin{abstract}
Purpose of the study: The purpose of the current study is to get subjective information from SMEs about their views and elicit the experience of getting loans and why not getting loans.

Methodology: This study has been used qualitative research and findings have been gathered using face-to-face in-depth semi-structured interviews.

Main Findings: Findings showed that there are two types of SME firms categorized in 1) Firms that are willing to take a loan but unable to get them and 2) Firms that have access to finance but don't want to obtain them, different themes have been extracted from the aforementioned categorization.
\end{abstract}

Applications of this study: This research can be effective to develop an economy in terms of employment generation, human resource development, value addition, poverty alleviation, income equality, entrepreneurial culture, and innovation, and Pakistan is no exception in this regard.

Novelty/Originality of this study: The study is contributing to running a manufacturing unit, usually a large land area is required. Moreover, business locations are preferred near to markets for ease of doing business. Since all these preferred choices require a lot of money to incur for capital expenditure which is hardly available for SMEs.

Keywords: Access to Finance, SMEs, Bank Credit, Bank Lending Policy, Economic Growth.

\section{INTRODUCTION}

Credit creation is one of the essential elements in any economy (Guttmann, 2016), and the role of financial intermediaries, especially the role of banks can never be neglected in credit creation (Gennaioli et al., 2014). In any economy, banks play a significant role by providing loans to corporate, commercial, and SME businesses (Bernardo \& Campiglio, 2014). These loans, or more specifically, credit generation, are considered as blood circulation for the survival of any business (Akhavein et al., 2005).

Many scholars and policymakers have generated considerable interest in accessing debt finance for various forms of businesses through formal sources like banks etc. However, according to the literature, several issues have been reported for the rejection of loan applications and the non-availability of debt financing from banks. One such issue that is under debate is that why do some borrowers are presented with substantially different loan conditions than other borrowers with the same credit risk? Why does the reported volume of credit differ for various classes of borrowers? (Nickerson, 2016).

While addressing these questions, numerous factors have been identified by various authors from both supply-side perspectives (Lenders perspective). These contributing factors include credit rationing by banks (McNamara et al., 2020), discrimination (Fernández et al., 2019), lending rates (Andries et al., 2018), transaction cost (Ajuwon et al., 2018), location of the business (Mertzanis, 2017), firm age (Adomako et al., 2016), firm size (Adomako et al., 2016), industry (Do et al., 2019), ownership type (Teles, 2018), financial transparency (Ellul et al., 2016), collateral (Osano \& Languitone, 2016), financial literacy (Hashim et al., 2018), gender (Morsy, 2020) and experience (Cowling et al., 2018), etc.

These aforementioned reasons are stem from the supply side perspective (lender's perspective) and do not cover the borrower's perspective that why the total lending portfolio of SMEs are negligible as compared to the corporate sector? Keeping in view the statistics that there are around about 3.2 million businesses in Pakistan out of which 3 million belong to the SME sector thus comprising $90 \%$ of the total business sector. Contributing $25 \%$ share in total earnings of Pakistan, 30\% to GDP, and employing more than 70\% of the total labor force (Khan, 2015). However, the share in total credit outstanding is on declining trend despite various initiatives taken by the government, so in this regard borrowers' perspective which are SMEs are needed to be investigated to find the actual cause of the decline in the SME loan outstanding over the period as per the reports of SBP $\underline{(\text { SBP, 2020). }}$.

\section{The objective of the Study}

The purpose of the current study is to get subjective information from SMEs about their views and elicit the experience 
of getting loans and why not getting loans. Using grounded analysis this study intends to fill this gap by identifying factors that hinder enhancing access to debt finance from borrowers' perspective. A good understanding of these determinants/factors shall significantly improve the researcher's knowledge of the sector and shall prove very meaningful support targeted for policymakers.

\section{LITERATURE REVIEW}

In recent years, many scholars and policymakers have shown interest regarding issues like credit availability and access to debt finance problems faced by small enterprises (Calabrese et al., 2020; Kautonen et al., 2020; Wasiuzzaman \& Nurdin, 2019). The interest is seen because small businesses play a significant role in the economic development of any country (Erdin \& Ozkaya, 2020; Gherghina et al., 2020; Mishra, 2019). Recent researchers have stated difficulties with external access to debt finance, which is encountered by the small business owner for the development and growth of their business in developing countries (Calabrese et al., 2020; Ghisetti \& Montresor, 2020; Khan \& Anuar, 2018).

Access to finance can be bifurcated into two streams of literature, one stream follows the formal source of the finance usually involves financial intermediaries. Another stream follows the informal source of finance usually involves friends, family, and trade creditors (Claessens \& Tzioumis, 2006; Connolly \& Bank, 2020; Kuntchev et al., 2012). On the formal side of debt finance, two streams exist. One involves the locations of the financial institution which is far away from the location of the business. Other streams are involved when the business has access to the location of the financial institution (Sugie, 2019; Tulasi et al., 2017).

Access to debt financing relies on the absence of hurdles for the utilization of financial services, whatever these hurdles are price or non-price to finance (Beck et al., 2009; Brixiová et al., 2020). This ensures that businesses and individuals have access without any barriers to financial services e.g., (Deposit, loans, payment, insurance, and trade credit). Consequently, it is necessary to differentiate between the genuine users who have access to financial services of the bank and non-users who do not use them while they have opportunities to use the financial services, either they avoid because of religious or cultural responsibilities or they decided that they do not want to use these financial services while having the access (Er \& Mutlu, 2017; Ozili, 2018; Ozili, 2020). This is due to several factors, like the cost of services and high fees, low income, lack of knowledge/information, or unreasonable requirements for opening the account in the bank, ultimately these factors provide results in failure of the enterprises who are non-user, which end up exiting the market (Fernández et al., 2018).

There are two dimensions of access to financial services. The first one is the demand-side and the second is the supply side (Nega \& Hussein, 2016; Yang et al., 2020). The dimension of the demand-side considers the option made by an individual in connection with services offered by the financial institutions (Tefera, 2019), on the other hand, the supply side discusses the financial intermediation or provision of financial services (Brixiová et al., 2020). In the economic literature, there are many theories linked to decision-making, which are a theory of rationality, the bounded theory of rationality, the theory of prospect, theory of intertemporal, satisficing theory, the theory of information asymmetry, theory of transaction cost, and theory of delegated monitoring (Scholtens \& Van Wensveen, 2003). The factors of the supply side are included from the following theories, which have already been thoroughly studied in the area of access to finance.

One of the key theories focusing on the financial gap is credit rationing that is presented by Stiglitz \& Weiss (1981). According to them, there is a dispute between shareholders and managers who manage the affairs of the businesses on behalf of the company's owners and that's why the agency issue arises between shareholders and managers. They also contended that only small and medium-scale enterprises understand exactly their ability to repay debt, financial positions, and profitability in investment. Stiglitz \& Weiss (1981) concluded that in tandem with information asymmetry, the agency problem was the key driver of adverse selection risk and moral degradations. The options for various forms of finance in terms of credit rationing and asymmetric information were further clarified by (Stiglitz \& Weiss, 1981). Asymmetry of information may lead to situations of credit rationing by altering the distribution of riskreturn. This allows banks to reject financial applications and thus contributes to gaps in demand and supply divergences (Trovato \& Alfò, 2006).

SMEs in emerging and developing economies had very limited access to formal credit because of incompetency in small-scale lending, the comparatively underdeveloped existence of the financial system, and lack of liquidity (Motta \& Sharma, 2020). Mazanai and Fatoki (2012) apprise that four factors are considered as key factors that banks are reluctant to lend to SMEs. These are the problem of information asymmetry (Yin et al., 2020), the operating costs of small loans are very high (Do et al., 2019), Collateral issues (Xu, 2019), and perceived high risk of SMEs (Osano \& Languitone, 2016). The above-mentioned reasons applied to both developing and developed economies. However, these reasons to the countries which are developed are more important there. The costs of handling loans of SMEs are often fixed, and they are often inefficient considering the limited scenario of the quantities demanded by SMEs and are therefore too expensive for the banks. Banks do not have the means to slash administrative expenses. it is also asserted that the administrating expenses of banks regarding loans to SMEs tend to be much higher as banks must have to visit SME premises to collect information, interpret information and track the lending (Green, 2003). SMEs are not usually in the 
proximity of metropolitan centres, often with no accountancy and have inadequate financial documents. The author further added that banks do not have the requisite expertise to support small and medium-sized enterprises.

Mole and Namusonge (2016) assume that banks charge high-interest rates typically when lending to small and mediumsized companies. High-interest rates are charged due to the "high riskiness" of small businesses, further also involves "high cost" while fetching information of the SMEs through the different lending technologies. It is pertinent to mention here that the high interest rate charged by the banks is not always deliberate but sometimes it's not in the control of the bank to charge a high-interest rate. Ardic et al. (2012) find out in their research that high transaction cost is always problematic for small and medium enterprises as well as for financial institutions. The apparent cause of high transaction cost is the fetching of the creditworthiness of the borrower from the various sources, due to that reason and the small lending volume banks struggle to serve SMEs. Banks usually never deliberately uses this method for fetching information, but banks evaluate corporate/commercial enterprises and SMEs on the same scale.

On the other dimension of the demand side of access to finance (North et al., 2010), various theories give some insight into why SMEs are willing and why some are not willing to take a loan from the banks. Agency theory denotes a state where the owners of the small businesses and stakeholders, such as workers, financiers, and others with a bestowed interest in the organization in the context of SMEs (Mazanai \& Fatoki, 2012). Under agency theory, the small business owner is presumed to be interested in the daily operations of the company and to handle its finances on its own without taking loans but rather depended on trade loans, but many small enterprises were managed by the management other than the owner with specialist experience and aimed at expanding the business through debt financing.

Mole and Namusonge (2016), discussed another theory from the demand perspective that was the pecking order theory in SMEs context in which they appraised that how the SMEs manage their working capital and how they arrange funds from different sources of finance. According to their explanation, small companies tend to use different sources of finances to finance their businesses. Further, under the domain of this theory, it is discussed and assumed that usually the owners of the SMEs prioritise their finances primarily from the equity and then debt and it could be hybrid. In this regard, it is supposed that the first funding of small business owners comes from earnings, followed by debt, and then by hybrid instruments.

Fatoki (2014) has reported that macro-economic factors such as interest rate, exchange rate, and inflation rates affect loan supply and demand. when there is a slowdown in the economy of any country, banks usually restrict the lending volume and adopt the risk-averse mode to reduce the loans to become non-performing loans and consequently maintain or increase the profit. Many small and medium-sized companies do not know who provides funds to them and what type of financial instruments are most suitable for them. Besides, they find that SMEs are not generally aware of the financing for which they are eligible. Instead, much time is wasted on contacting the wrong types of sponsors and qualifying for the form of support that does not meet or does not necessarily qualify for their needs.

\section{METHODOLOGY}

The researchers were encouraged to opt qualitative research method due to the exploratory nature of the current study. The qualitative research approach aims to provide an in-depth, socio-contextual, and thorough explanation and analysis of the research topic. Broadly speaking, Qualitative research provides the in-depth and narrow perspective of relevant study to become more focused on an area of study, whereas quantitative research provides a wider and shallow view of applied study. Therefore, the present study took an in-depth view to understand the current state of SME financing.

\section{Sample Profile}

For the qualitative study, 45 business owners from diverse industries were interviewed through the theoretical sampling technique. Data collection stops when theoretical saturation is reached which means the point when no new insight is added to conceptual categories with new interviews. The owners of 26 Manufacturing firms and 19 Trading firms participated in the study. Of the total 45 participants, 33 were Small Enterprises and 12 were Medium Enterprises as defined by the State bank of Pakistan. The business experience of 5 participants was up to 5 years, followed by 22 participants having business experience between 6 to 10 years, followed by 10 participants having business experience between 11 to 20 years, followed by 8 participants having business experience over 20 years. In the sample, 16 participants were Sole Proprietors, 6 participants were associated with partnership business and 5 participants were associated with Single Member companies or Limited Liability companies.

Table 1: Sample Profile

\begin{tabular}{lll}
\hline Characteristics & Count & Percentage \\
\hline Business Sector & & \\
\hline Manufacturing & 26 & $58 \%$ \\
\hline Trading & 19 & $42 \%$ \\
\hline Years of Business Experience & & \\
\hline Up to 5 years & 5 & $11 \%$ \\
\hline $6-10$ Years & 22 & $49 \%$ \\
\hline
\end{tabular}




\begin{tabular}{lll}
\hline $11-20$ Years & 10 & $22 \%$ \\
\hline Over 20 Years & 8 & $18 \%$ \\
\hline Years of Banking Relationship & & \\
\hline Up to 5 years & 18 & $40 \%$ \\
\hline $5-10$ Years & 15 & $33 \%$ \\
\hline $11-20$ Years & 9 & $20 \%$ \\
\hline Over 20 Years & 3 & $7 \%$ \\
\hline Education & & \\
\hline 10 years (Matriculation) & 12 & $27 \%$ \\
\hline 12 Years (Intermediate) & 21 & $47 \%$ \\
\hline 14 years (Graduate) & 10 & $22 \%$ \\
\hline 16 Years (Masters) \& Above & 2 & $4 \%$ \\
\hline Type of Business Organization & & \\
\hline Sole Proprietorship & 16 & $36 \%$ \\
\hline Partnership & 6 & $13 \%$ \\
\hline Company & 5 & $11 \%$ \\
\hline Business Size Classification & & \\
\hline Small Enterprises & 33 & $73 \%$ \\
\hline Medium Enterprises & 12 & $27 \%$ \\
\hline
\end{tabular}

\section{Procedure}

Semi-structured interviews were conducted using the interview protocol in January 2020. Each interview was held by one of the three interviewers, including the author, and continued for 25 minutes approximately. Overall, 45 businessmen shown their willingness to appear in the interviews which continued for approximately 19 hours in total. To start a formal interview the below mentioned thematic questions were presented for discussion;

1. What is your preferred mode of finance in case of capital requirement for business?

2. How did you experience commercial banks in a lending role?

3. Which factors influence SMEs to get financial accommodation other than the banking channel.

We have transcribed the interviews and have run a word frequency query based on weightage to see what the participants have talked about the most. The results are shown below figure. The most words used by the participants were business, loan, commercial, financing, collateral, autonomy, documentation, and so on.

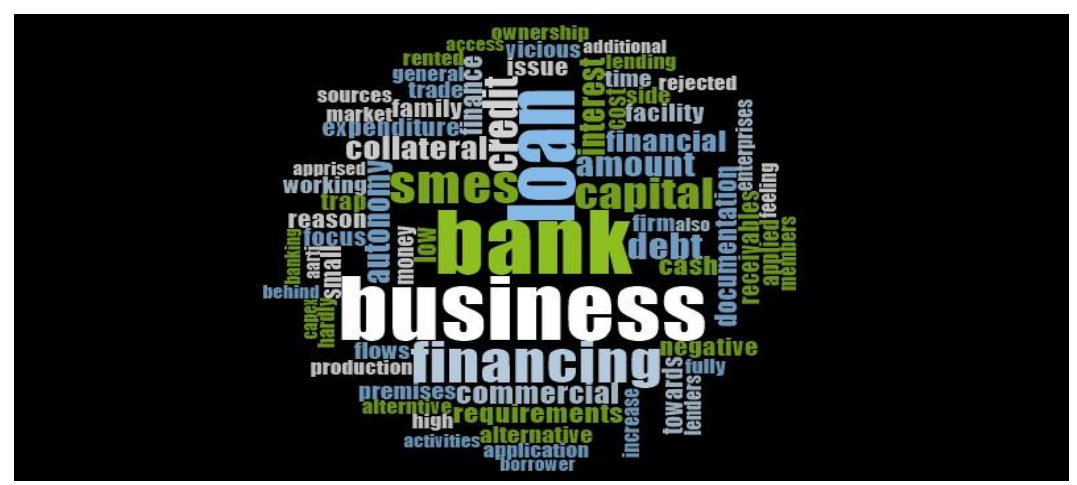

Figure 1: Pictorial representation of most common Words

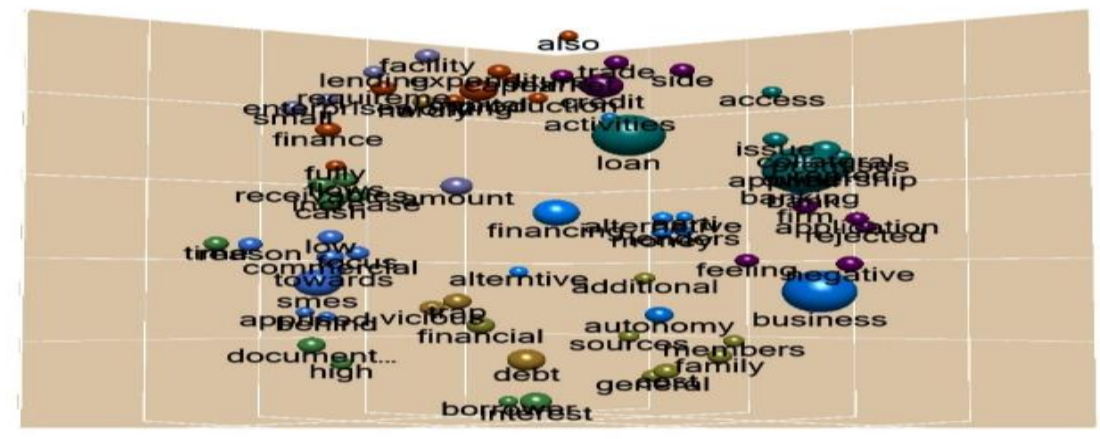

Figure 2: Pictorial representation of most common words 
We have conducted 45 interviews then manually coded them to generate 12 nodes including the low focus commercial banks towards SME financing, business premises ownership, and collateral issue, CAPEX financing, high-interest rates \& loan documentation, negative business list \& gut feeling, increasing receivables draining cash flows, trade credit, alternative financing, vicious debt trap, SEs beliefs of banks are not lending, business autonomy and religiosity and spirituality affect.

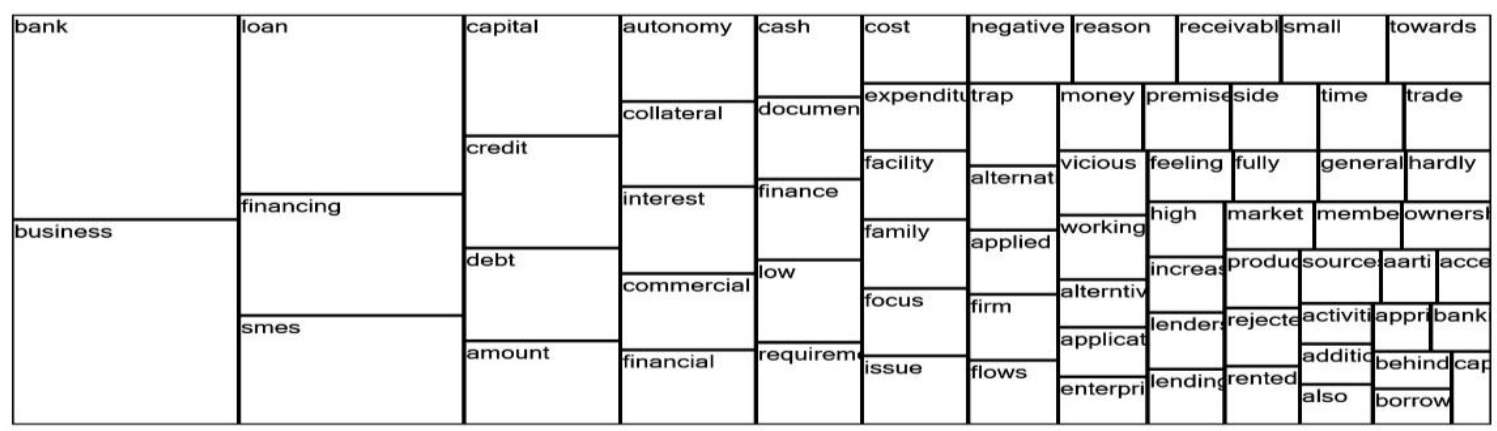

\section{Analysis Strategy}

We have used NVIVO 12 software to conduct thematic analysis. It follows a qualitative descriptive design. This technique analyses textual data and reveals themes. It is a six-step process including familiarizing with data, generating initial codes, searching themes, reviewing themes, defining and naming themes, and producing a report (Braun \& Clarke, 2014). Thematic analysis was chosen as a 'rigorous thematic approach that can produce an insightful analysis that answers particular research questions' (Braun \& Clarke, 2006). Then, themes were identified from the collected interviews. A theme captures the main idea from the data related to research questions and identifies patterns or meanings in the data (Braun \& Clarke, 2006).

\section{RESULTS/FINDINGS/ANALYSIS}

Through data analysis, twelve categories have emerged. Table 2 describes the emerging categories and quotations of participants.

Table 2: Categories Representing the State of SME Financing

\begin{tabular}{lrl}
\hline Categories & & Representative Quotation \\
\hline Low Focus & of & Banks prefer to finance large businesses due to multiple reasons, particularly to meet \\
Commercial & Banks & allocated targets. We believe, bankers do not discriminate intentionally with SMEs rather it \\
towards & SME & is the system where mammoth targets shall only be achieved if large size loans are booked. \\
Financing. & & (SME Trading Sector, Interview 01)
\end{tabular}

Business Premises Collateral requirements considerably vary from small to large size banks. A loan was Ownership \& rejected by one bank due to collateral ownership by a third party and the same was approved Collateral Issue by another bank that was comparatively small in size. (Manufacturing Sector, Interview 5).

CAPEX Financing We are availing working capital loan from the bank, but we have been refused capital expenditure financing. Further bank officials advised approaching lease finance companies for getting such type of finance. (Manufacturing Sector, Interview 7).

High-Interest Rates \& I applied for bank financing and emphasized charging a low-interest rate as my competitors Loan Documentation were allowed bank loans at fine pricing. However, I have been conveyed that initially you will be charged bank standard mark-up rates, which was almost double as compared to peer companies. (Manufacturing Sector, Interview 9).

We are running two manufacturing integrated units and to meet business working capital requirements, applied for a bank loan with both firm names and there-against offered single

Negative Business List \& Gut Feeling security/collateral. After necessary processing, bank officials responded that they can offer a loan facility in the name of one firm only since the second business line falls under our negative business list. The loan refusal interrupted my entire business-enhancement plan as it was not feasible to run the second unit without financial support. (Manufacturing Sector, Interview $11,13 \& 29)$.

I experienced that the entire market is ready for credit purchases instead of cash purchases.

Increasing Receivables draining cash flows
Even large distributors or wholesalers take consignment from small manufacturers and sometimes ask to get paid upon sale of the consignment. This increasing credit sales merely tempting SMEs to increase accounts receivables and have a little impact on the firm's growth. In this scenario, getting financial accommodation from financial institutions on an interest basis does not seem so feasible. (Manufacturing Sector, Interview $24 \& 44$ )

\begin{tabular}{lll}
\hline Trade Credit & Suppliers of goods usually allow 30 days trade credit, which is sometimes extended up to 40 \\
\hline 139 |https:/giapjournals.com/hssr/index & C) Elahi et al.
\end{tabular}


days or even more without charging any additional cost or penalty which is applicable in case of bank financing. (SME Trading/Manufacturing Sector Interview 4 \& 19).

We grow our crops while having pre-arrangement of crop auctioning through Arthi (money

Alternative Financing lenders/commission agents). Under this arrangement, Arthi during the period of crop production provides certain facilities and services to us. During crop production and harvesting season, we get a considerable amount in advance from money lenders to meet our living expenses and don't go for bank financing. (Interview 33, 45).

I availed bank loans and utilized them from one business plan to another and so on. Gradually bank loan volumes were also increased to ensure the availability of sufficient Vicious Debt Trap funds to successfully execute every new business plan. By doing this I considerably expanded business volumes, but at the cost of low profitability as a lot of business, profit is taken by the bank in the shape of debt cost every year. Now, I want to get rid of debt to avoid debt costs, but it does not seem feasible to me so far. (Manufacturing Sector, Interview 17). I availed bank loans and utilized them from one business plan to another and so on. Gradually bank loan volumes were also increased to ensure the availability of sufficient funds to successfully execute every new business plan. By doing this I considerably expanded business volumes, but at the cost of low profitability as a lot of business, profit is taken by the bank in the shape of debt cost every year. Now I want to get rid of debt to avoid debt cost, but it does not seem feasible to me so far. (Manufacturing Sector, Interview 11 \& 3)

SEs beliefs of Banks are not lending:

Our forefathers were used to get credit from business friends on a need basis. Besides this, in

Business Autonomy the ordinary course of business, they prefer to perform business activities with available resources and we are following the same practice with great comfort. (Manufacturing Sector, Interview $16 \& 27)$.

I belong to a business-oriented family and growing up my business skills under the strong

Religiosity

Spirituality Affect and leadership of elder family members. Whenever I feel financial constraints then obvious options are my friends and family members to get financial assistance since there is too much influence of family members to avoid interest-based loans from financial institutions. (Manufacturing Sector, Interview 28 \& 31).

\section{Low Focus of Commercial Banks towards SME Financing}

The research participants demonstrated that undoubtedly from every corner of the world, it is widely acknowledged that SMEs are very important and should be supported to perform their economic role for the betterment of the economy. Besides this, there is a bitter reality that practically SMEs are discriminated against in almost every sphere of business, particularly concerning financial accommodation due to multiple reasons.

\section{Trade Credit}

SMEs enjoying goodwill in the market prefers to avail trade credit, which further strengthens their market relationships and networking. The participants stated that, unlike banks where the number of critical formalities is involved to get financial accommodation comparatively at a higher cost, does not suit their business model.

\section{Business Premises Ownership \& Collateral Issue}

The research participants indicated that commercial banks have stringent policies regarding ownership of the collateral while loan evaluation of SMEs. They acknowledged that Banks do not lend money without collateral, but collateral requirements considerably vary from small to large size banks.

\section{Capital Expenditure Finance}

The research participant appraised that SMEs running manufacturing concerns, must upgrade their production units or replace machinery parts with new ones to keep the production unit fully operational. However, it has been widely witnessed that Banks are not willing to extend financing facilities for the purchase of fixed assets. On an alternate basis, manufacturing firms usually have pre-arrangements with leasing companies to finance machinery and related items being imported through commercial banks. Due to this SMEs remain unprivileged to get benefited from the latest and upgraded manufacturing units to improve their production capacity or reduce overhead cost.

\section{High-Interest Rates \& Loan Documentation}

The research participants expressed that SMEs are being charged high-interest rates by commercial banks. It is imperative to add that high interest does not mean that banks are charging interest rate over their standard rates as mentioned in their schedule of charges rather SMEs claims to allow them financial accommodation at low-interest rates like corporate customers who are getting financial facilities at lower interest rates than banks' standard interest rates. 


\section{Negative Business List \& Gut Feeling}

The research participants indicated that SMEs are now getting the very common response of banks that their business falls in the negative list of bank or bank financing to specific business sectors has been banned, so their credit application cannot be processed.

\section{Increasing Receivables Draining Cash Flows}

The research participants demonstrated that as per ruling market practice, manufacturers make credit sales with flexible credit terms to new customers. Despite offering a flexible payment plan to wholesalers, distributors, and retailers, they are habituated to hold payment of an initial consignment order and continue to make payments of the rest of the consignment orders as per agreed arrangements. The research participants expressed another point of concern that if credit sale is made with 30 days' payment and the same is received after 40 days, then in this situation buyers do not bear bank interest charges of an additional 10 days. To retain the customer, we as SMEs forcefully avoid claiming additional 10 days' charges/cost from customers.

\section{Alternative Financing}

The research participants having agrarian businesses or good economical backgrounds indicated that their business operations are handled in such a way to keep them away from financial institutions.

\section{Business Autonomy}

The research participants indicated that SMEs are more concerned with their business decisions and are not willing to compromise on their freedom regarding when to make a decision, what work to be done, and how it will be done. It is a pre-requisite of banks that financial accommodation shall be allowed for a specific purpose and any deviation shall adversely influence credit arrangements between borrowers and lenders. Due to this, SMEs often avoid bank financing and prefer to perform their business activities with available resources.

\section{Vicious Debt Trap}

The research participants indicated that it is so easy to inject fresh capital into the business, but to withdraw the same from the business is far difficult. SME borrowers, despite having the intention to get rid of debt-obligation, failed to do so. They always remained under debt obligation or even debt size increased due to their accelerated working capital requirements.

\section{SEs believe' Banks are not lending}

The research participants disclosed that Small Enterprises desperately made their mind to never apply for a bank loan since it is more hectic with a lot of documentation, time-consuming, and in the end hardly getting the nominal amount of the loan amount which is far lesser than of required one. The research participants experienced that banks are not willing to offer the required financial facility (Loan) despite fulfilling loan formalities including collateral requirements. Banks have stringent policies for SMEs, particularly for small enterprises (SE) while allocating financial facilities. This leads to unequal distribution of wealth which is a big hurdle in the development and prosperity of SMEs.

\section{Religiosity and Spirituality Affect}

The research participants indicated that SMEs who belong to religiously active families usually avoid interest. There is a general concept among their families to avoid bank loans and to conduct business with their sources to earn Halal (permissible) income. They particularly refer following verse of the Holy Quran which contains commands of Almighty Allah Who regards usury (interest);

\section{CONCLUSION}

This study is qualitative in nature and provides an overview of the current state of SME Financing from SMEs' perspective in Pakistan. This study highlights concerns of SMEs about bank financing and also investigates factors that influence SMEs' to refrain from bank finance. It contributes to building an understanding of Policymakers for SME promotion, Banking Policy, and Regulation Departments and particularly financial institutions about common issues of SMEs which are still overlooked. The data gathered through interviews depict that SMEs do not consider commercial banks as the ultimate provider of financial accommodation. The business strategies of banks are not yet designed which can meet the specific needs of SME Borrowers as banks are tilted towards booking large-size customers and not promoting Small Enterprises access to finance which is a big hurdle to unleash the potential of the SME sector. The results demonstrate that big banks have more stringent policies concerning collateral ownership and its status as compared to small size banks while extending loans to SMEs. The manufacturing firms are usually not being extended finance facilities for acquiring non-current assets rather they have to enter into lease finance agreements with leasing companies in this regard. SMEs also are of the view that the Gut feeling of bankers also influences their lending decisions and mostly the reason for loan rejection is not shared with them. The results also indicate that SMEs are normally charged standard mark-up rates, particularly for fresh loans which are high as compared to large size customers. 
On the other hand, SMEs find the trade credit facility as the best possible alternative to Bank financing. The economic and market conditions also influence Banks' decision while giving loans to SMEs which otherwise merely result in increasing receivables with an extensive cost. Besides this, private lenders fleeced borrowers by offering financial accommodation without following formal lending procedures like banks but indirectly charge a considerable interest cost. Moreover, some other factors like Business Autonomy, Vicious Debt Trap, and Religiosity effect have a considerable influence on SMEs approach to get financial accommodation.

The results of the current study have significant implications for commercial banks and policymakers. It is a dire need of the hour to set a focused approach and design banking business strategies for SME promotion to reveal the potential of this sector. In this regard, the statistics should be prepared about market size and their financing requirements and thereagainst specific targets comprised on numbers and volumes should be allocated to commercial banks for SME financing. With the collaboration of policymakers and commercial banks, joint surveys can be scheduled to make this activity more transparent and meaningful. This activity shall also play a vital role in the confidence-building of SMEs over commercial banks and to increase SMEs loan application rate as well. Understanding of market size, industry trends \& outlook shall enable lenders to gauge prudential borrowing requirements of SMEs and ultimate utilization of funds for business growth and their effective contribution to the overall economic growth of the country. Besides this, by building effective banking relationships, SMEs can diminish the issue of asymmetric information and increase their probability of getting the loan as well.

\section{LIMITATION AND STUDY FORWARD}

There are some limitations of the study, which are imperatively mentioned here. The themes produced in this study have been thoroughly reviewed and verified by another research scholar, however subjectively interpreted data, which is innate in the qualitative thematic analysis can ponder concerns. Next to it, research participants may extravagant their concerns regarding SME financing since they are facing lending discrimination and are not being extended financial accommodation as per their requirements so our finding may be affected by sensitivity bias.

Further research can be conducted to identify factors of SME borrowers who have been successfully sanctioned the required loan amount, with the borrowers' and lenders' perspectives separately. Moreover, the other potential areas for future study could be revamped policies to avoid discrimination in SME financing by commercial banks. Another important area could be a comparative study of SME lending policies of large and small size banks in Pakistan.

\section{ACKNOWLEDGEMENT}

Thank you to all my co-authors and colleagues, who have supported me so well in carrying out my research. I would also like to thank my family for their support in this research paper. I have the opportunity to complete this paper because of their unconditional love and prayers.

\section{AUTHORS CONTRIBUTION}

Ali Raza Elahi: He has constructed the main study's introduction and literature review. He assisted counters in interviews with respondents. He also has good skills to carry out interviews in native languages.

Alia Ahmed: She has largely been involved in conceptualizing the field of study, focused audience, discussions and findings, suggestions, restrictions, and future directions for research.

Safyan Majid: He has helped in providing business contacts for interviews and convert the audio files into MS Word format.

Muhammad Farhan Asif: He has established the design and methodology of this study. He has evaluated the statistics with different techniques.

\section{REFERENCES}

1. Adomako, S., Danso, A., \& OforiDamoah, J. (2016). The moderating influence of financial literacy on the relationship between access to finance and firm growth in Ghana. Venture Capital, 18(1), 43-61. https://doi.org/10.1080/13691066.2015.1079952

2. Ajuwon, O., Ikhide, S., \& Akotey, J. (2018). Financing MSMEs (Micro Small and Medium Enterprises) in Nigeria: Implications of Transaction Costs. Preprints, 2018100576. https://doi.org/10.20944/preprints2 01810.0576.v1

3. Akhavein, J., Frame, W. S., \& White, L. J. (2005). The diffusion of financial innovations: An examination of the adoption of small business credit scoring by large banking organizations. The Journal of Business, 78(2), 577-596. https://doi.org/10.1086/427639

4. Andries,, A. M., Marcu, N., Oprea, F., \& Tofan, M. (2018). Financial infrastructure and access to finance for European SMEs. Sustainability, 10(10), 3400. https://doi.org/10.3390/su10103400

5. Ardic, O. P., Mylenko, N., \& Saltane, V. (2012). Access to finance by small and medium enterprises: a cross-country analysis with a new data set. Pacific Economic Review, 17(4), 491-513. https://doi.org/10.1111/j.1468-0106.2012.00596.x 
6. Beck, T., Demirgüç-Kunt, A., \& Honohan, P. (2009). Access to financial services: Measurement, impact, and policies. The World Bank Research Observer, 24(1), 119-145. https://doi.org/10.1093/wbro/lkn008

7. Bernardo, G., \& Campiglio, E. (2014). A simple model of income, aggregate demand, and the process of credit creation by private banks. Empirica, 41(3), 381-405. https://doi.org/10.1007/s10663-013-9239-6

8. Braun, V., \& Clarke, V. (2006). Using thematic analysis in psychology. Qualitative Research in Psychology, 3(2), 77-101. https://doi.org/10.1191/1478088706qp063oa

9. Braun, V., \& Clarke, V. (2014). What can "thematic analysis" offer health and wellbeing researchers? International Journal of Qualitative Studies on Health and Well-being, 9(1). https://doi.org/10.3402/qhw.v9.2 $\underline{6152}$

10. Brixiová, Z., Kangoye, T., \& Yogo, T. U. (2020). Access to finance among small and medium-sized enterprises and job creation in Africa. Structural Change and Economic Dynamics, 55, 177-189. https://doi.org/10.1016/j.strueco.2020.08.008

11. Calabrese, R., Degl'Innocenti, M., \& Zhou, S. (2020). Expectations of access to debt finance for SMEs in times of uncertainty. Journal of Small Business Management, 1-28. https://doi.org/10.1080/00472778.2020.1756309

12. Claessens, S., \& Tzioumis, K. (2006). Measuring firms' access to finance. World Bank,1-25.

13. Connolly, E., \& Bank, J. (2020). Access to small business finance. RBA Bulletin, September.

14. Cowling, M., Liu, W., \& Zhang, N. (2018). Did firm age, experience, and access to finance count? SME performance after the global financial crisis. Journal of Evolutionary Economics 28(1), 77-100. https://doi.org/10.1007/s00191-017-0502-Z

15. Do, P., Phong, V., VanThuong, P., Tien, N., \& VanDung, H. (2019). Factors Affecting Access to Finance By Small and Medium Enterprises In Vietnam. American International Journal of Business Management, 2(10), 69-79.

16. Ellul, A., Jappelli, T., Pagano, M., \& Panunzi, F. (2016). Transparency, tax pressure, and access to finance. Review of Finance 20(1), 37-76. https://doi.org/10.1093/rof/rfv005

17. Er, B., \& Mutlu, M. (2017). Financial inclusion and Islamic finance: A survey of Islamic financial literacy index. Uluslararası Íslam Ekonomisi ve Finansı Araştırmaları Dergisi, 3(2).

18. Erdin, C., \& Ozkaya, G. (2020). Contribution of small and medium enterprises to economic development and quality of life in Turkey. Heliyon, 6(2). https://doi.org/10.1016/j.heliyon.2020.e03215

19. Fatoki, O. (2014). The causes of the failure of new small and medium enterprises in South Africa. Mediterranean Journal of Social Sciences, 5(20), 922-922. https://doi.org/10.5901/mjss.2014.v5n20p922

20. Fernández-Olit, B., Martín, J. M. M., \& González, E. P. (2019). Systematized literature review on financial inclusion and exclusion in developed countries. International Journal of Bank Marketing, 38(3), 600-625. https://doi.org/10.1108/IJBM-06-2019-0203

21. Fernández-Olit, B., Paredes-Gázquez, J. D., \& de la Cuesta-González, M. (2018). Are social and financial exclusion two sides of the same coin? An analysis of the financial integration of vulnerable people. Social Indicators Research 135(1), 245-268. https://doi.org/10.1007/s11205-016-1479-y

22. Gennaioli, N., Martin, A., \& Rossi, S. (2014). Sovereign default, domestic banks, and financial institutions. The Journal of Finance, 69(2), 819-866. https://doi.org/10.1111/jofi.12124

23. Gherghina, Ș. C., Botezatu, M. A., Hosszu, A., \& Simionescu, L. N. (2020). Small and Medium-Sized Enterprises (SMEs): The Engine of Economic Growth through Investments and Innovation. Sustainability, 12(1), 347. https://doi.org/10.3390/su12010347

24. Ghisetti, C., \& Montresor, S. (2020). On the adoption of circular economy practices by small and mediumsize enterprises (SMEs): does "financing-as-usual" still matter? Journal of Evolutionary Economics, 30(2), 559-586. https://doi.org/10.1007/s00191-019-00651-w

25. Green, A. (2003). Credit guarantee schemes for small enterprises: an effective instrument to promote private sector-led growth? UNIDO, Programme Development and Technical Cooperation Division.

26. Guttmann, R. (2016). How Credit-money Shapes the Economy: The United States in a Global System: The United States in a Global System: Routledge. https://doi.org/10.4324/9781315485973

27. Hashim, A., Omar, C. M. C., Hamzah, M. G., \& Umar, A. (2018). Leadership Behaviour, Entrepreneurial Orientation and Organisational Performance in Malaysian Small and Medium Enterprises. International Business Research, 11(9), 37-50. https://doi.org/10.5539/ibr.v11n9p37

28. Kautonen, T., Fredriksson, A., Minniti, M., \& Moro, A. (2020). Trust-based banking and SMEs' access to credit. Journal of Business Venturing Insights, 14, e00191. https://doi.org/10.1016/i.jbvi.2020.e00191

29. Khan, S. (2015). Impact of sources of finance on the growth of SMEs: evidence from Pakistan. Decision, 42(1), 3-10. https://doi.org/10.1007/s40622-014-0071-z

30. Khan, S., \& Anuar, A. R. (2018). Access to finance: Exploring barriers to entrepreneurship development in SMEs. In Global Entrepreneurship and New Venture Creation in the Sharing Economy, IGI Global, 92-111. https://doi.org/10.4018/978-1-5225-2835-7.ch006

31. Kuntchev, V., Ramalho, R., Rodríguez-Meza, J., \& Yang, J. S. (2012). What have we learned from the Enterprise Surveys regarding access to finance by SMEs. Enterprise Analysis Unit of the Finance and Private Sector Development, The World Bank Group. https://doi.org/10.1596/1813-9450-6670 
32. Mazanai, M., \& Fatoki, O. (2012). Access to finance in the SME sector: A South African perspective. Asian journal of business management, 4(1), 58-67.

33. McNamara, A., O'Donohoe, S., \& Murro, P. (2020). Lending infrastructure and credit rationing of European SMEs. The European Journal of Finance, 26(7-8), 728-745. https://doi.org/10.1080/1351847X.2019.1637357

34. Mertzanis, C. (2017). Ownership structure and access to finance in developing countries. Applied Economics, 49(32), 3195-3213. https://doi.org/10.1080/00036846.2016.1257106

35. Mishra, N. (2019). Knowledge management practice for effective operations in SMEs. Production Planning \& Control, 30(10-12), 795-798. https://doi.org/10.1080/09537287.2019.1582108

36. Mole, S. A., \& Namusonge, G. (2016). Factors affecting access to credit by small and medium enterprises: A case of Kitale Town. The International Journal of Social Sciences and Humanities Invention, 3(10), 29042917. https://doi.org/10.18535/ijsshi/v3i10.12

37. Morsy, H. (2020). Access to finance-mind the gender gap. The Quarterly Review of Economics and Finance, 78(0), 12-21. https://doi.org/10.1016/j.qref.2020.02.005

38. Motta, V., \& Sharma, A. (2020). Lending technologies and access to finance for SMEs in the hospitality industry. 86, 102371. https://doi.org/10.1016/j.ijhm.2019.102371

39. Nega, F., \& Hussein, E. (2016). Small and medium enterprise access to finance in Ethiopia: Synthesis of demand and supply.

40. Nickerson, D. (2016). Asset price volatility, credit rationing and rational lending discrimination. International Journal of Economics and Finance, 8(10), 140-158. https://doi.org/10.5539/ijef.v8n10p140

41. North, D., Baldock, R., \& Ekanem, I. (2010). Is there a debt finance gap relating to Scottish SMEs? A demand-side perspective. Venture Capital,12(3), 173-192. https://doi.org/10.1080/13691061003658670

42. Osano, H., \& Languitone, H. (2016). Factors influencing access to finance by SMEs in Mozambique: case of SMEs in Maputo central business district. Journal of innovation and entrepreneurship, 5(1), 13. https://doi.org/10.1186/s13731-016-0041-0

43. Ozili, P. K. (2018). Impact of digital finance on financial inclusion and stability. Borsa Istanbul Review, 18(4), 329-340. https://doi.org/10.1016/j.bir.2017.12.003

44. Ozili, P. K. (2020). Theories of financial inclusion. In Uncertainty and Challenges in Contemporary Economic Behaviour: Emerald Publishing Limited. https://doi.org/10.1108/978-1-80043-095-220201008

45. SBP. (2020). Policy for Promotion of SME Finance.

46. Scholtens, B., \& Van Wensveen, D. (2003). The theory of financial intermediation: an essay on what it does (not) explain: Paper presented at the Journal of the European Money and Finance Forum.

47. Stiglitz, J. E., \& Weiss, A. (1981). Credit rationing in markets with imperfect information. The American economic review, 71(3), 393-410.

48. Sugie, A. (2019). Deconstructing Financial Inclusion and Exclusion in the Development. Rural areas between regional needs and global challenges 97-119. https://doi.org/10.1007/978-3-030-04393-3_6

49. Tefera, K. T. (2019). Determinants of Access to Finance for Micro and Small Scale Enterprises in Nekemte Town. Research Journal of Finance and Accounting, 10(19). https://doi.org/10.1080/10.7176/RJFA/10-19-04

50. Teles, A. M. C. (2018). Access to finance and the type of ownership: do different firms behave differently when constrained?

51. Trovato, G., \& Alfò, M. (2006). Credit rationing and the financial structure of Italian small and medium enterprises. Journal of Applied Economics , 9(1), 167-184. https://doi.org/10.1080/15140326.2006.12040643

52. Tulasi, G., Golait, R., Sethi, M., \& Goel, S. (2017). Involuntary exclusion and the formal financial sector. Economic and Political Weekly, 52(36), 67-72.

53. Wasiuzzaman, S., \& Nurdin, N. (2019). Debt financing decisions of SMEs in emerging markets: empirical evidence from Malaysia. International Journal of Bank Marketing, 37(1), 258-277. https://doi.org/10.1108 /IJBM-12-2017-0263

54. Xu, B. (2019). Permissible collateral and access to finance: Evidence from a quasi-natural experiment. China Economic Review, 54, 237-255. https://doi.org/10.1016/j.chieco.2018.11.006

55. Yang, W., Li, H., Kong, G., \& Kong, D. (2020). Access to finance and SMEs' trade credit: evidence from a regression discontinuity design. Accounting \& Finance. https://doi.org/10.1111/acfi.12691

56. Yin, C., Jiang, C., Jain, H. K., \& Wang, Z. (2020). Evaluating the credit risk of SMEs using legal judgments. Decision Support Systems, 136, 113364. https://doi.org/10.1016/j.dss.2020.113364 